\title{
Uterine Corpus Cancer pT3b TNM Finding v6
}

National Cancer Institute

\section{Source}

National Cancer Institute. Uterine Corpus Cancer pT3b TNM Finding v6. NCI Thesaurus. Code C61351.

Uterine corpus cancer with tumor involvement of the vagina either from direct extension or metastasis. (from AJCC 6th Ed.) 